\title{
REACTION OF ALLICIN-RELATED COMPOUNDS WITH PROTEIN ${ }^{1}$
}

\author{
ISAMU UTSUMI, KIYOSHI HARADA AND KEIICHI KOHNO² \\ Osaka Research Laboratory, Tanabe Seiyaku Co., Litd., Osaka
}

(Received April 1, 1964)

\begin{abstract}
Fujiwara et al. $(1-2)$ reported that allicin was bound with egg albumin or blood protein in vitro and also with body constituents in vivo. They assumed that allicin was not chemically bound with the SH groups of protein, but it was additionally bound forming a complex. Allicin was not liberated from the "complex" by washing with water or saturated ammonium sulfate solution, but could be easily separated by extracting with ethanol in which allicin is easily soluble. When protein is deprotenized by metaphosphoric acid or salted out by ammonium sulfate from the mixed system of a relatively hydropholic substance as allicin and dissolved protein, there is a possibility of enfolding of allicin. Without fractional determination and identification of the unreacted allicin, the allicin which could not be separated by washing alone, cannot be ascribed to the formation of complex with the protein. In the previous paper (3) it was confirmed that symmetric disulfides, such as thiamine disulfide (TDS) or $O$-benzoylthiamine disulfide (BTDS), reacted with the SH groups of protein, forming a protein-S-S-thiamine type compound. Allicin homologs are known to react easily with L-cysteine, forming $S$-alkyl-mercapto-L-cysteine (4-5). It is therefore expected that the SH groups of egg or serum albumin can also easily react with allicin homologs since they have a specific reactivity for the SH group of cysteine. In order to solve these questions the interaction of allicin homologs, $\mathrm{C}_{3} \mathrm{H}_{7} \mathrm{SSC}_{3} \mathrm{H}_{7}$ (I) or $\mathrm{C}_{3} \mathrm{H}_{7}$ $\mathrm{SSOC}_{3} \mathrm{H}_{7}$ (II), with egg albumin was investigated. It was recognized that each of $\mathrm{I}$ and II reacted with the $\mathrm{SH}$ group of egg albumin, forming a chemically bound compound, protein-S-S- $\mathrm{C}_{3} \mathrm{H}_{7}$, though the reaction mechanism were somewhat different between the two compounds.
\end{abstract}

\section{EXPERIMENTAL}

\section{Materials}

$\mathrm{C}_{3} \mathrm{H}_{7} \mathrm{SSC}_{3} \mathrm{H}_{7}(\mathrm{I})$ and $\mathrm{C}_{3} \mathrm{H}_{7} \mathrm{SSOC}_{3} \mathrm{H}_{7}(I I)$ - I was redistilled and the fraction having a boiling-point of $97-98^{\circ}(30 \mathrm{mg} \mathrm{Hg})$ was used. II was prepared by the procedure of Yoshimura (6) as follows. To a solution of $600 \mathrm{mg} \mathrm{I}$ in 4 $\mathrm{ml}$ glacial acetic acid was added $0.4 \mathrm{ml}$ of $30 \%$ hydrogen peroxide and the mixture was allowed to stand at room temperature for 24 hours. It was diluted

\footnotetext{
${ }^{1}$ Studies on Interaction of Thiamine or its Related Compounds with Protein. VII Preliminarily reported at the 138th Meeting of Vitamin B Research Committee (8).

2 内海: 勇, 原田清, 河野啓一。
} 
with ethanol up to $50 \mathrm{ml}$, and was employed as a $0.08 M$ stock solution. In the reaction with protein, the stock solution was neutralized under ice cooling with $N \mathrm{NaOH}$ and a $0.04 M$ solution was used in the experiment.

Egg Albumin — Egg albumin powder, Difco, was dissolved to make a $5 \%$ solution. A small amount of insoluble material was removed by centrifugation at $4000 \mathrm{rpm}$ for 15 minutes.

\section{Reaction and Deproteinization}

To $5 \mathrm{ml}$ of $5 \%$ egg albumin (in case of urea denaturation $6 \mathrm{~g}$ urea was added) were added $4 \mathrm{ml}$ of $0.5 M$ phosphate buffer ( $\mathrm{pH} 7.4), 0.8 \mathrm{ml}$ of $0.1 M$ I solution in ethanol or $2 \mathrm{ml}$ of $0.04 \mathrm{M}$ II solution in $50 \%$ ethanol, and water was added up to $15 \mathrm{ml}$. The mixture was incubated at $37^{\circ}$ for one hour with agitation. In order to remove the unreacted I or II, deproteinization was carried out as follows. To the reaction mixture $30 \mathrm{ml}$ of ethanol and $5 \mathrm{ml}$ of $10 \%$ metaphosphric acid were added. The protein was precipitated by centirifugation at $4000 \mathrm{rpm}$ for 10 minutes, the precipitate was suspended in $40 \mathrm{ml}$ of ethanol and the whole was heated at $60^{\circ}$ for 15 minutes, followed by centrifugation. This extraction procedure was repeated three times using $40 \mathrm{ml}$ of ethanol. The protein fraction thus obtained was diluted to a suitable volume with water for further experiments.

\section{Assay of Protein-bound $\mathrm{C}_{3} \mathrm{H}_{7} \mathrm{SH}$ and Unreacted I and II}

To each sample, containing less than $50 \mu \mathrm{g}$ as $\mathrm{C}_{3} \mathrm{H}_{7} \mathrm{SH}, 5 \mathrm{ml}$ of $0.5 \mathrm{M}$ phosphate buffer, $\mathrm{pH} 8.0$, and $20 \mathrm{mg}$ of cysteine hydrochloride were added and the final volume was made up to $12 \mathrm{ml}$ with water. After incubation at $37^{\circ}$ for one hour, the mixture was acidified with hydrochloric acid and the liberated $\mathrm{C}_{3} \mathrm{H}_{7} \mathrm{SH}$ was extracted with $10 \mathrm{ml}$ of chloroform. 2 to $5 \mathrm{ml}$ of the extract was placed into a glass-stopperd tube and chloroform was added up to about $10 \mathrm{ml}$. Then 10 $\mathrm{ml}$ of $3 \times 10^{-5} \mathrm{M} \mathrm{HgCl}_{2}$ in $\mathrm{N} \mathrm{H}_{2} \mathrm{SO}_{4}$ solution was added and the whole was vigorously agitated for 2 minutes. $5 \mathrm{ml}$ of the water layer was taken and the remaining $\mathrm{HgCl}_{2}$ was determined by the dithizon method (7), and the $\mathrm{HgCl}_{2}$ consumed was calculated. The amount of $\mathrm{C}_{3} \mathrm{H}_{7} \mathrm{SH}$ was determined according to the following formulae.

$$
\begin{aligned}
& \mathrm{C}_{3} \mathrm{H}_{7} \mathrm{SH}+\mathrm{HgCl}_{2} \longrightarrow \mathrm{C}_{3} \mathrm{H}_{7} \mathrm{SHgCl}+\mathrm{HCl} \\
& 1 \mathrm{ml} \text { of } 3 \times 10^{-5} \mathrm{M} \mathrm{HgCl}_{2} \text { corresponds to } 2.28 \mu \mathrm{g} \mathrm{C}_{3} \mathrm{H}_{7} \mathrm{SH}
\end{aligned}
$$

One mole of $\mathrm{C}_{3} \mathrm{H}_{7} \mathrm{SH}$ was found to consume $0.95 \pm 0.05$ mole of $\mathrm{HgCl}_{2}$ in the range of 2 to $20 \mu \mathrm{g}$ of the mercaptan under the condition given above, and a small amount of alkylmercaptan could be determined with $95 \pm 5 \%$ recovery. But the recoveries were about $60 \%$, when I or II was determined after reduction with cysteine. Several reducing methods were tried but they were all unsatisfactory. When $\mathrm{C}_{3} \mathrm{H}_{7} \mathrm{SH}$ was treated with cysteine, the recovery was also lowered than that without cysteine treatment. However, this assay method is more sensitive than any other methods and the procedure is simple. Therefore, it was adopted for the following experiments. The remained II in the supernatant was also determined from the amount of the masked thiamine according to Fujiwara et al. (2) 


\section{RESULTS AND DISCUSSION}

1. Separation of Remaining I or II in the Protein Fraction and Determination of Bound Propylmercaptan

After incubation of native or urea-denatured egg albumin with I or II, ethanol or metaphosphoric acid was added and the protein fraction collected by centrifugation was extracted with hot ethannol several times and the amount of $\mathrm{I}$ or II contained in each extract was assayed after reduction to $\mathrm{C}_{3} \mathrm{H}_{7} \mathrm{SH}$. The amount of II was also determined from the amount of masked thiamine. The results are illustrated in Figs. 1 and 2. Deproteinization and extraction with ethanol in



Fig. 1 Ethanol Extraction of the Reac. tion Product of Egg Albumin with I - denatured protein with I; $O$, native protein with I

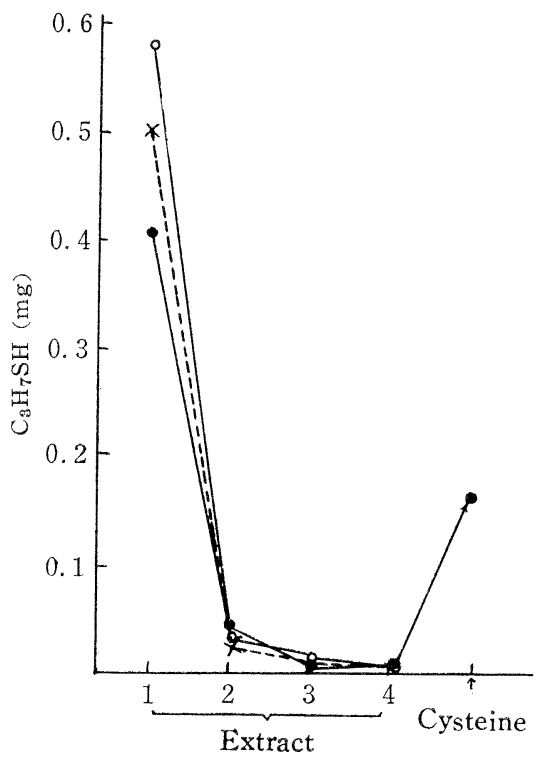

Fic. 2 Ethanol Extraction of the Reaction Product of Egg Albumin with II

- denatured protein with II ; $O$, denatured protein with II (determined from the amount of masked thiamine); $\times$, native protein with II (determined from the amount of masked thiamine)

which these disulfides are readily soluble, followed by deproteinization with metaphosphoric acid and further extraction with hot ethanol 3 to 4 times is assumed to be capable of completely eliminating the occurrence of "enfolding" of the unchanged I or II. Each protein was then treated with cysteine and amount of $\mathrm{C}_{3} \mathrm{H}_{7} \mathrm{SH}$ which was expected to have been formed, was determined and a significant amount of the mercaptan was detected. (Figs. 1 and 2). Howrever, in the case of the reaction of $\mathrm{I}$ with the native protein, the amount of $\mathrm{C}_{3} \mathrm{H}_{7} \mathrm{SH}$ thus liberated was very small. In the supernatant, a large amont of $\mathrm{C}_{3} \mathrm{H}_{7} \mathrm{SH}$ was detected after incubation of the denatured protein with I, but scarcely any mercaptan was found after incubation with II. From these results it was assumed that I reacted with the $\mathrm{SH}$ - groups of the denatured protein, whearas II reacted 
with the SH-groups of the native or denatured protein, producing the compound bound with protein, a compound similar to $S$-alkylmercaptocysteine, according the following formulae.

$$
\begin{aligned}
& \operatorname{Pr}(\mathrm{SH})_{\mathrm{n}}+\mathrm{n} \mathrm{C}_{3} \mathrm{H}_{7} \mathrm{SSC}_{3} \mathrm{H}_{7} \rightleftarrows \operatorname{Pr}\left(\mathrm{SSC}_{3} \mathrm{H}_{7}\right)_{\mathrm{n}}+\mathrm{n} \mathrm{C}_{3} \mathrm{H}_{7} \mathrm{SH} \quad \text { (a) } \\
& \mathrm{O}
\end{aligned}
$$

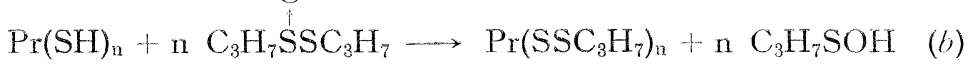

$$
\begin{aligned}
& \mathrm{O}
\end{aligned}
$$

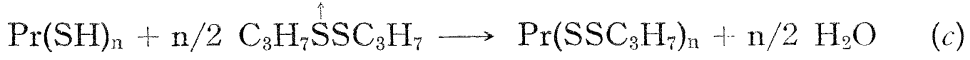

\section{Effect of Inhibitors of Protein-SH Groups}

The findings given above suggest that the compound bound with protein is not an additional complex as assumed by Fujiwara but a compound chemically bound with the $\mathrm{SH}$ groups of protein, as have been proved by the authors in the cases of TDS and BTDS. For further confirmation, the effects of various inhibitors of the SH-groups were investigated.

Effect of Iodine Oxidation Urea-denatured protein, $250 \mathrm{mg}$, was oxidized with $0.1-0.2 \mathrm{ml}$ of $0.1 \mathrm{~N}$ iodine solution. After the reaction of the oxidized protein with $\mathrm{I}$ or II, the amount of the $\mathrm{C}_{3} \mathrm{H}_{7} \mathrm{SH}$ bound with protein was determined. As shown in Fig. 3, the amount of the mercaptan bound with protein was decreased according to the increase of iodine.

Inhibition by $P C M B-$ Native or denatured protein was treated with a certain amount of $1.6 \times 10^{-2} M$ p-chloromercuribenzoate $(\mathrm{PCMB})$ solution, incubated with $I$ or II and the protein-bound compound thus formed was determined. As shown in Fig 4, the formation of protein-bound mercaptan was markedly decreased with the increase of the bloking of $\mathrm{SH}$-groups. These findings indicate that

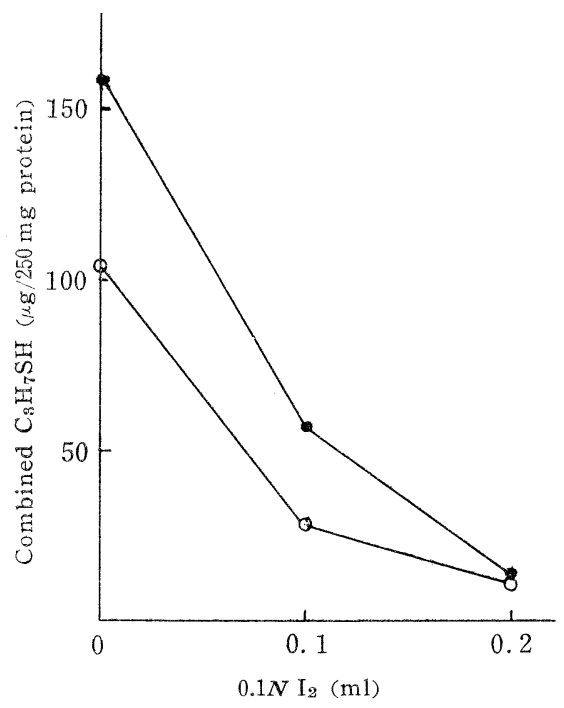

FIG. 3 Effect of Oxidation with Iodine Reaction: $250 \mathrm{mg}$ denatured protein $\rightarrow$ oxidized $\rightarrow+12 \mathrm{mg} \mathrm{I}$ or II; pH $7.4 ; 37^{\circ} 1 \mathrm{hr}$. $\mathrm{O}, \mathrm{I}$;

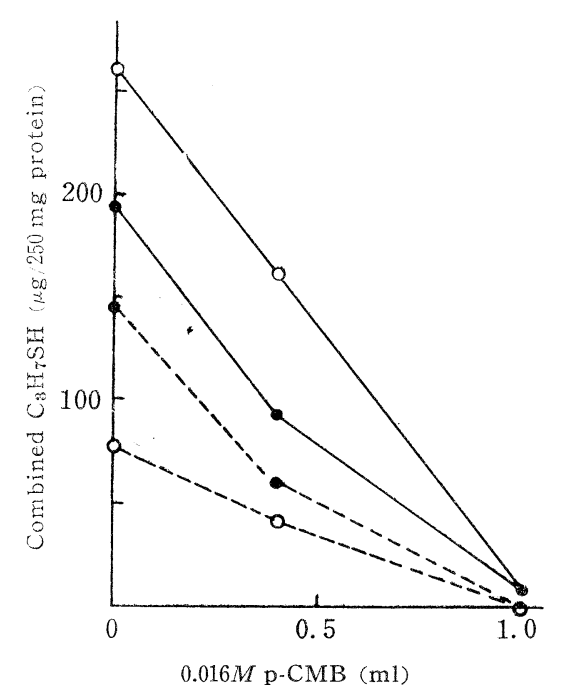

Fig. 4 Effect of Inhibition by PCMB Reaction: $250 \mathrm{mg}$ protein $\rightarrow$ block with $\mathrm{PCMB} \rightarrow+12 \mathrm{mg}$ I or II ; $\mathrm{pH} 9.0 ; 37^{\circ} ; 1 \mathrm{hr}$. $\mathrm{O}, \mathrm{I}$; $\mathrm{II}$; -, denatured; -.., native 
the $\mathrm{SH}$ - groups of protein are involved in the formation of protein-bound propylmercaptan by the reaction of egg albumin with I or II, and that this complex is of a $S$-propylmercapto-cysteine type.

\section{Effects of $p H$, Time and Temperature}

Urea-denatured protein was incubated with I or II in the buffer solution of various $\mathrm{pH}$ levels and the amount of propylmercaptan bound with the protein are listed in Table I. As can be seen from the Table, the reaction of the SH-groups of the protein with II in the range of $\mathrm{pH} 6.0$ to 9.0 remains almost the same, but the reaction with $I$, as in the case with TDS and BTDS, is definitely influenced by the $\mathrm{pH}$ level, the bound amount being markedly increased at the $\mathrm{pH}$ levels above 7.0. Generally in the SH-disulfide exchange reaction as formula $(a)$, the $\mathrm{SH}$ is considered to participate in the reaction with the dissociated form $\left(\mathrm{RS}^{-}\right)$. Therefore, in the case of the SH-groups of the protein, its dissociated form $\left(\mathrm{PrS}^{-}\right)$is assumed to be involved in the reaction; the higher the $\mathrm{pH}$, the greater the concentration of $\mathrm{PrS}^{-}$with the proportional rise in reactivity.

Reaction Time and Temperature-In the formation of the complex like $\mathrm{PrSSC}_{3} \mathrm{H}_{7}$, the reaction is naturally assumed to depend on the temperature and

TABLE I

Effect of $p H$

\begin{tabular}{|c|c|c|c|c|c|c|c|c|}
\hline \multirow{2}{*}{ Disulfide } & \multicolumn{8}{|c|}{$\mathrm{pH}$ levels } \\
\hline & 3.0 & 5.0 & 6.2 & 7.5 & 7.8 & 8.2 & 8.6 & 9.0 \\
\hline \multicolumn{9}{|c|}{$\mu g \mathrm{C}_{3} H_{7} \mathrm{SH}$ bound with $250 \mathrm{mg}$ protein } \\
\hline I & 7 & 18 & 52 & 109 & 157 & 253 & 270 & 252 \\
\hline II & 117 & 113 & 165 & 150 & 116 & 178 & 203 & 175 \\
\hline
\end{tabular}

Reaction : $25 \mathrm{mg}$ protein $+6 \mathrm{~g}$ urea $+12 \mathrm{mg}$ I or II ; $1 \mathrm{hr}$.

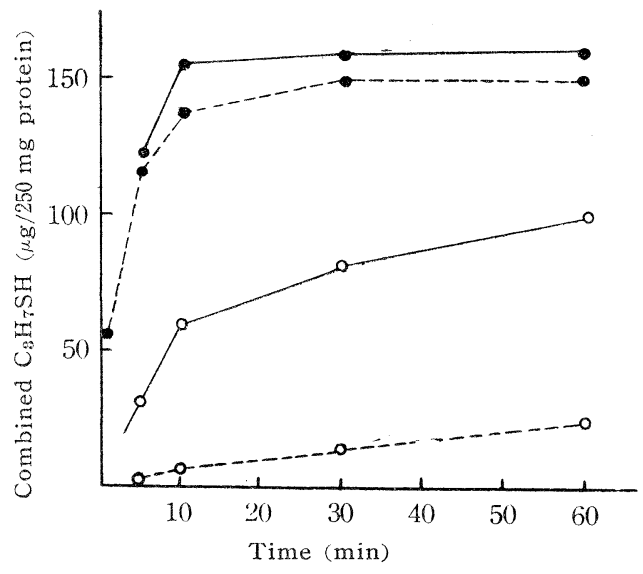

FIg. 5 Effect of Time and Temperative

Reaction: $250 \mathrm{mg}$ denatured protein $+12 \mathrm{mg}$

I or II ; pH 7.3

O, I; •, II ; $\cdots, 10^{\circ} ;-, 37^{\circ}$ 
time. The protein was therefore allowed to react at $10^{\circ}$ or $37^{\circ}$ and $\mathrm{pH} 7$ and the amount of combined propylmercaptan was determined at each interval. As shown in Fig 5, in the reaction with $\mathrm{I}$, the effects of temperature and time are marked even at $37^{\circ}$ and it took considerably a long time for reaching the equilibrium state at $10^{\circ}$. In the case of II, however, these effects were observed only within 10 minutes from the start of the reaction, scarcely any increase in the bound form being detected thereafter, indicating that the compound II was more reactive than I towards the SH-groups of the protein. These findings show that the complex with protein is not a mere additional one but the formation of the compound bound by chemical reaction.

\section{Effect of Protein Denaturation}

The amount of the propylmercaptan bound with protein was markedly increased in the case of I by denaturation of protein, but in the case of II, the complex was produced regardless of denaturation or nativity of the protein. The finding was further studied in detail. Table II shows that in the case of I, similarly to the cases of TDS and BTDS, the amounts of bound and free propylmercaptan rose with the degree of denaturation of the protein, suggesting the process of the equibrium reaction $(a)$.

TABLE II

Effect of Protein Denaturation

\begin{tabular}{|c|c|c|c|c|c|c|}
\hline \multirow{2}{*}{ Disulfide } & \multirow{2}{*}{$\begin{array}{l}\mathrm{C}_{3} \mathrm{H}_{7} \mathrm{SH} \\
\text { produced }\end{array}$} & \multicolumn{5}{|c|}{ Urea used for protein denaturation $(\mathrm{g} / 15 \mathrm{ml})$} \\
\hline & & 0 & 2 & 3 & 4 & 6 \\
\hline & & \multicolumn{5}{|c|}{$\mu \mathrm{g}$ bound and free $\mathrm{C}_{3} \mathrm{H}_{7} \mathrm{SH}$ produced from $250 \mathrm{mg}$ protein } \\
\hline I & $\begin{array}{l}\text { Free } \\
\text { Bound }\end{array}$ & $\begin{array}{l}40 \\
31\end{array}$ & $\begin{array}{l}71 \\
43\end{array}$ & $\begin{array}{r}177 \\
59\end{array}$ & $\begin{array}{r}177 \\
71\end{array}$ & 194 \\
\hline II & $\begin{array}{l}\text { Free } \\
\text { Bound }\end{array}$ & $\begin{array}{r}15 \\
154\end{array}$ & $\begin{array}{r}13 \\
162\end{array}$ & $\begin{array}{r}18 \\
180\end{array}$ & $\begin{array}{r}23 \\
182\end{array}$ & $\begin{array}{r}22 \\
176\end{array}$ \\
\hline
\end{tabular}

Reaction : $250 \mathrm{mg}$ protein + urea $+12 \mathrm{mg}$ I or II, pH 7.3, $1 \mathrm{hr} ., 37^{\circ}$

On the other hand, compound II reacted also with the thiol groups of the native protein and the amount of the propylmercaptan bound with the protein rose a little after denaturation. The formation of free propylmercaptan was very little, a finding compatible with the process of the reactions $(b)$ and $(c)$.

\section{SUMMARY}

Native or urea-denatured egg albumin was allowed to react with $\mathrm{C}_{3} \mathrm{H}_{7} \mathrm{SSC}_{3} \mathrm{H}_{7}$ (I) or $\mathrm{C}_{3} \mathrm{H}_{7} \mathrm{SSOC}_{3} \mathrm{H}_{7}$ (II) under a certain condition. The protein was precipitated by ethanol treatment and the unreacted I or II was completely removed by extracting the precipitate several times with hot ethanol. The protein fraction was reduced by cysteine, producing the free propylmercaptan. It is assumed to have been produced ifrom the compound bound with the protein similarly to $S$-propylmercapto-cysteine. As the microdetermination of propylmercaptan was possible by utilizing dithizon method, the amount of the bound propylmercaptan under various 
contions was investigated and the following results were obtained.

1. The formation of the bound form of I was markedly increased by protein denaturation, producing also the free propylmercaptans. The formation of the bound form of II was somewhat increased after denaturation of the protein, but was observed significantly with the native protein. In this case the formation of free propylmercaptan was scarcely observed.

2. The reaction of $\mathrm{I}$ with the protein was markedly dependent on $\mathrm{pH}$ levels, rising definitely at $\mathrm{pH}$ levels above 7.0. On the other hand, the reaction of II was little affected by $\mathrm{pH}$ levels, showing almost a constant activity at $\mathrm{pH}$ range above 6.0.

3. The reactivity of I or II was increased with the rise of temperature and time.

4. When the SH-groups of the protein were oxidized with iodine or blocked by $p$-chloromercuribenzoate, the reactivity was remarkably reduced.

These findings suggest that the compound I or II, though the reaction mechanisms are different from each other, reacts with the SH-groups of the protein, forming a protein-bound compound like protein-SS- $\mathrm{C}_{3} \mathrm{H}_{7}$.

\section{ACKNOWLEDGMENT}

The authors wish to express their gratitude to Dr. Masao Fujisawa and Norio Sugimoto of our company for their constant encouragment.

\section{REFERENCES}

1. Fujiwara, M., Murakami, F., Fujiwara, K., Vitamins 17, 138, (1959).; 20, 136, (1960).

2. Fujiwara, M., ibid. 21, 461, (1960).

3. Utsumi, I., Harada, K., Kohno, K. and Hirao, H., J. Vitaminol. 9, 41, 50, 89, (1963).

4. Cavallito, C.J., Buck, J.S. and Suter, C.M., J. Amer. Chem. Soc. 66, 1952, (1944).

5. Yurugi, S., Yakugaku Zasshi 74, 511, 514, (1954).

6. Yoshimura, M., Vitamins 14, 627, (1958).

7. Sandell, E.B., Colorimetric Metal Analysis, 2nd ed., p. 444, Interscience Publishers, Ltd., (1956). 